Central Washington University

ScholarWorks@CWU

History Faculty Scholarship

College of Arts and Humanities

Summer 2016

\title{
The Effect of Military Service on Indian Communities in Southern New England, 1740-1763
}

Brian D. Carroll

Central Washington University

Follow this and additional works at: https://digitalcommons.cwu.edu/cahfac_history

Part of the Indigenous Studies Commons, and the United States History Commons

\section{Recommended Citation}

Carroll, Brian D. "The Effect of Military Service on Indian Communities in Southern New England, 1740-1763." Early American Studies: An Interdisciplinary Journal 14, no. 3 (2019): 506-536.

This Article is brought to you for free and open access by the College of Arts and Humanities at ScholarWorks@CWU. It has been accepted for inclusion in History Faculty Scholarship by an authorized administrator of ScholarWorks@CWU. For more information, please contact scholarworks@cwu.edu. 


\title{
The Effect of Military Service on Indian Communities in Southern New England, 1740-1763
}

\author{
BRIAN D. CARROLL \\ Central Washington University
}

\begin{abstract}
Military sources combined with existing ethnohistorical narratives about the experience of Algonquian groups living "behind the frontier" in colonial southern New England provide insight into the effect of imperial warfare on Indian peoples. Virtually every indigenous male in the region after King Philip's War served in the colonial military. Tribes used the service of their men as leverage in negotiations with colonial governments as they attempted to advance their own agendas and protect their sovereignty. Yet Indian soldiers died in large numbers, mainly from infectious disease. Death rates for Indian soldiers were so high that they affected tribal demographics and led to increasing intermarriage and intermixing between the region's Indian and African populations. Other issues faced by Natives in the aftermath of the wars included the long-term injury and disability of veterans, the unresolved fate of men captured during the fighting, and the psychological effect of wartime trauma on veterans.
\end{abstract}

On August 7, 1757, at the height of the French and Indian War (175463), known as the Seven Years' War (1756-1763) in Europe, just two days

The author thanks Richard D. Brown for comments on an earlier version of this piece. Also, thanks to Marna Carroll for numerous suggestions and to Zydric Purdy and Andrew Pierce for references. The author is grateful for the assistance of staff at a number of institutions, including the Massachusetts State Archives, the Massachusetts Historical Society, the American Antiquarian Society, the Huntington Library, and the Connecticut Historical Society. Research for this work was made possible through a fellowship from the University of Connecticut Humanities Institute, the Kate B. and Hall J. Peterson Fellowship from the American Antiquarian Society, the Robert L. Middlekauff and Mayers fellowships from the Huntington Library, and travel grants and a research leave provided by the College of Arts and Humanities at Central Washington University.

Early American Studies (Summer 2016)

Copyright (C) 2016 The McNeil Center for Early American Studies. All rights reserved. 
before the capitulation and "massacre" at Fort William Henry on Lake George, Elisha Tupper, 250 miles to the east, visited the Herring Pond Indian reservation near Sandwich, Massachusetts. Four Indian preachers, Samuel Francis, Isaac Jeffery, Joseph Bryant, and Joseph Pepenau, formerly with the help of Tupper's late father, Eldad, ministered to the Wampanoags at Herring Pond and a number of smaller communities nearby. Herring Pond's population was 150; the smaller communities numbered between 17 and 40. Visiting at the behest of New England's leading missionary society, Tupper tallied the number of Indians in the area attending Christian worship. He marked crosses after the names of fourteen of the thirty-three men and noted, "the men that have this ${ }^{\circ}$ mark are gone . . . in the Army." According to Tupper, 42 percent of Herring Pond's men were in the military. Of the remaining nineteen, eight either had served in the army during King George's War (1744-48) or in an earlier campaign in the current conflict, or would enlist subsequently (the war lasted another five years). So, two-thirds of adult males from Herring Pond had taken part in at least one military campaign — many had served multiple deployments. But given the incompleteness of records from King George's War, the percentage is probably higher. This is more than twice the rate Fred Anderson calculated for men from Massachusetts as a whole during the war for empire, and it corroborates Richard Johnson's claims that Indians bore more than twice the burden of fighting in the colonial wars than whites. ${ }^{1}$

Half of the fourteen Herring Pond men in the service in 1757 enlisted in the same provincial company, led by Captain Peter West. The campaign proved disastrous for both West's command and Herring Pond. Some of the unit's men were inside Fort William Henry when it capitulated. Two Herring Pond members died: one was killed during the French assault and

1. Elisha Tupper, "Indians who Dwell near and attend the Worship of God in Sandwich Indian meeting House," August 7, 1757, Miscellaneous Bound Manuscripts (hereafter cited as Misc. MSS), Massachusetts Historical Society, Boston (hereafter cited as MHS). To determine who the veterans were, I used Massachusetts Soldiers in the Colonial Wars, NewEnglandAncestors.org (Boston: New England Historic Genealogical Society, 2002); William Pepperell Papers, Collections of the Massachusetts Historical Society, 6th ser., 10 (1899); and various muster lists from the Massachusetts Archives Series, Massachusetts State Archives, Boston (hereafter cited as Mass. Archives); Fred Anderson, A People's Army: Massachusetts Soldiers and Society in the Seven Years' War (Chapel Hill: University of North Carolina Press, 1984), 60-61; Richard R. Johnson, "The Search for a Usable Indian: An Aspect of the Defense of Colonial New England," Journal of American History 64, no. 3 (1977): 623-51. 
the other was taken prisoner by Indians allied with the French and subsequently died in captivity. Three others deserted from West's company after numerous skirmishes, a smallpox outbreak, and the massacre following the surrender of Fort William Henry. ${ }^{2}$

A population breakdown shows that years of military service dramatically affected the composition of Indian communities in New England like Herring Pond. Already by 1757 adult women outnumbered men 57 to 43 percent. Herring Pond conducted another census when it petitioned the same missionary society for funds to repair the meetinghouse in 1761 . Four more years of war led to additional deaths. The overall population decreased 15 percent. The number of males dropped to 38 percent of the total population. And Herring Pond was not alone. Indian communities across the region reported similar declines as a result of their men dying in the army during the late colonial wars. A census of Potanomecut, a Nauset community on Cape Cod, taken near the end of the war, showed twenty-seven adult females and just fourteen males - again, as at Herring Pond, a ratio of two to one. Likewise, wartime casualties left shattered the Nauset bands of nearby Yarmouth and Eastham. In a 1757 petition the village headmen explained, "Many of our nation have entered into the war with the English against the French and Indian[s] in alliance with them and many of them have Died in the service \& left the squas \& children in distressing circumstances." The experience of the Niantic village in Lyme, Connecticut, was much the same. It had seventy-five inhabitants when the renowned minister, Ezra Stiles, visited in October 1761. Curious about local Indians, Stiles conversed with them, recorded their names and ages, and sketched a wigwam inhabited by George Waukeete's family and another owned by Phebe and Elizabeth Moheeges. Like Tupper at Herring Pond, he asked about the men fighting in the current war. Villagers told him eighteen Niantics had enlisted in the previous seven years, which was about four of ten males in the village and virtually all the young men. Half never returned. The war had claimed 11 percent of the tribe's population, and hostilities were not yet over. A local minister reported similar losses among the Pequots, twenty-five miles east. ${ }^{3}$ War devastated Native New England.

2. Undated list (ca. November 10, 1757), Josiah Thacher Diary, 1756-1757, Thacher Family Papers, MHS; Petition of Deborah Bristow, May 27, 1762, Mass. Archives, 80:213.

3. Benjamin Sepit et al., "The Names and Number of Indians Who Belong to or Attend the Indian Meeting in Sandwich," October 16, 1761, Misc. MSS; Petition of Isaac James et al., November 19, 1757, Mass. Archives, 33:10; Waukeete served in Captain Adonijah Fitch's company at the siege of Louisburg in 1745; 
During the colonial period indigenous peoples in the Northeast employed myriad strategies to ensure their survival in the face of invading European peoples, microbes, and beliefs. Serving as ethnic soldiers in the armed forces of the colonizing power was one of those strategies. Like all early modern European colonial empires, Britain incorporated certain conquered groups into its armed forces whom it perceived had an aptitude for war. In turn, these troops aided in the subjugation of other indigenous peoples. ${ }^{4}$ Virtually every Indian male in southern New England in the ninety years following King Philip's War served in the region's provincial armies. This made military service a near-ubiquitous experience for indigenous males and ensured that warfare remained integral to the regional Indian experience. New France's military reliance on Native warriors is well known, but the British also sought tribes as allies, if to a lesser extent and often less successfully. Although long noted, the incorporation of Native Americans into the armies of colonial New England has yet to be examined beyond several studies of the Stockbridge Mohicans and passing references by ethnohistorians analyzing the effects of cultural and economic change on the region's

Commissary's Book, 1745-1746, French and Indian War Papers, Connecticut Historical Society, Hartford (hereafter cited as CHS); Extracts from the Itineraries and Other Miscellanies of Ezra Stiles, D.D., LL.D, 1755-1794 . . . , ed. Franklin Bowditch Dexter (New Haven: Yale University Press, 1916), 130-31.

4. Cynthia Enloe first used the term ethnic soldiers to describe minorities in multiethnic states whom elites deemed trustworthy and suited to military service. Wayne E. Lee sees a group viewed as naturally suited to military service, often because of perceived ferocity, yet integrated into the same organizational and technological structure as the rest of an army as a "martial race." To him ethnic soldiers are members of a group recruited for their expertise in a particular style of warfare, especially one suited to local conditions. Cynthia Enloe, Ethnic Soldiers: State Security in a Divided Society (Athens: University of Georgia Press, 1982); Heather Streets, Martial Races: The Military, Race and Masculinity in British Imperial Culture, 1857-1914 (Manchester, U.K.: Manchester University Press, 2004); Wayne E. Lee, "Projecting Power in the Early Modern World: The Spanish Model?" in Lee, ed., Empires and Indigenes: Intercultural Alliance, Imperial Expansion, and Warfare in the Early Modern World (New York: New York University Press, 2011), 10, and Lee, "Subjects, Clients, Allies or Mercenaries? The British Use of Irish and Indian Military Power, 1500-1815,” in H. V. Bowen, Elizabeth Mancke, and John G. Reid, eds., Britain's Oceanic Empire: British Expansion in the Atlantic and Indian Ocean Worlds, c. 1550-1850 (New York: Cambridge University Press, 2012), 179-217; Tom Holm, "The Militarization of Native America: Historical Process and Cultural Perception," Social Science Journal 34, no. 4 (1997): 461-74. 
Indians. ${ }^{5}$ These soldiers came from Indian communities "behind the frontier" - those groups conquered, subjugated, or incorporated into colonial jurisdictions. ${ }^{6}$ They were Mohegans, Pequots, Niantics, Nipmucs, Wampanoags, Nausets, Narragansetts, and others, in addition to the Mohicans. They were deemed excellent frontier soldiers, and the demand for their martial skills gave Indians a strong bargaining position that they used to negotiate for preferential terms of service and economic benefits. Attempting to further tribal political goals, some groups used the service of their men as a bargaining chip in negotiations with colonial governments in the same way they did with the adoption of Christianity or notions of European land tenure. During the early imperial wars in the region (16891726) Algonquians usually served in the army in tribal units or all-Indian ranger companies specializing in reconnaissance and guerilla warfare. Indian soldiers constituted as much as 20 percent of troops on major campaigns. Demographic shifts, increasing acculturation and Christianization, greater Crown involvement, and changing ideas about race, however, resulted in a dramatically different military experience for Indians in New England during the second half of the eighteenth century. They became minority members of provincial regiments that used largely conventional tactics. ${ }^{7}$

5. Patrick M. Malone, The Skulking Way of War: Technology and Tactics among the New England Indians (Baltimore: Johns Hopkins University Press, 1991); Colin Calloway, The American Revolution in Indian Country: Crisis and Diversity in Native American Communities (New York: Cambridge University Press, 1995), 85-107; Daniel Mandell, Behind the Frontier: Indians in Eighteenth Century Massachusetts (Lincoln: University of Nebraska Press, 1996); Jean O'Brien, Dispossession by Degrees: Indian Land and Identity in Natick, Massachusetts, 1650-1790 (New York: Cambridge University Press, 1997); Amy E. Den Ouden, Beyond Conquest: Native Peoples and the Struggle for History in New England (Lincoln: University of Nebraska Press, 2005); David J. Silverman, Faith and Boundaries: Colonists, Christianity, and Community among the Wampanoag Indians of Martha's Vineyard, 1600-1871 (New York: Cambridge University Press, 2005); Ann Little, Abraham in Arms: War and Gender in Colonial New England (Philadelphia: University of Pennsylvania Press, 2007); and R. Todd Romero, Making War and Minting Christians: Masculinity, Religion, and Colonialism in Early New England (Amherst: University of Massachusetts Press, 2011).

6. Coined by Daniel Mandell, the term bebind the frontier describes tribal communities that were like "a few scattered islands in the English sea of eastern Massachusetts" after 1676. Conquered minorities facing "political and demographic subordination," these resilient communities nevertheless remained politically and culturally relevant. The phrase is used here as shorthand for Indians living under colonial jurisdiction; Mandell, Behind the Frontier, vii.

7. Brian D. Carroll, "From Warrior to Soldier: New England Indians in the Colonial Military, 1676-1763” (Ph.D. diss., University of Connecticut, 2009), 327-78. 
Life changed radically for Algonquians in southern New England in the late seventeenth and eighteenth centuries. Conquered and relegated to reservations, many converted to Christianity and selectively adopted European culture while retaining key elements of Native lifeways and worldview. Colonial power relations and environmental and economic conditions, however, assured that the incorporation of Indian peoples into the colonial economy was characterized by their poverty, indebtedness, and, for some, virtual enslavement through indentured servitude. By the end of the first quarter of the eighteenth century, most tribes barely eked out a living on small reservations on the fringes of colonial society. ${ }^{8}$ In this context, the wages offered by military recruiters proved irresistible to Indian men as opportunities to gain a livelihood and prove their masculinity in ways in keeping with Algonquian culture were increasingly circumscribed. Military service offered Indian men a path for gaining honor and prestige in demonstrably indigenous ways by allowing them to remain warriors. While missionaries and colonial leaders strove to "civilize" them in peacetime, other officials encouraged them to behave "savagely" and commit acts of "barbarism" in the service of empire. ${ }^{9}$

Ethnohistorians who study Native New England, such as Daniel Mandell, Jean O'Brien, David Silverman, and Amy E. Den Ouden, have noted that New England Indian men died in large numbers during the colonial wars - so many, in fact, that women came to constitute a significant majority of adults in Indian communities. Along with other factors, this led to widespread intermarriage and intermixing of Indian and African populations. While most studies note these losses and the intermixing that followed, few address other issues that Indians faced in the aftermath of the wars, such as long-term injury and disability of veterans, the unresolved fate of men captured during the fighting, and war's psychological effect on

8. Although by no means a complete list, relevant recent works on New England ethnohistory describing the effect of colonization on the region's Native population include Mandell, Bebind the Frontier, and Mandell, Tribe, Race, History: Native Americans in Southern New England, 1780-1880 (Baltimore: Johns Hopkins University Press, 2008); O'Brien, Dispossession by Degrees; Silverman, Faith and Boundaries; Den Ouden, Beyond Conquest; Jenny Hale Pulsipher, "Subjects unto the Same King": Indians, English, and the Contest for Authority in Colonial New England (Philadelphia: University of Pennsylvania Press, 2005); Romero, Making War and Minting Christians; and Linford D. Fisher, The Indian Great Awakening: Religion and the Shaping of Native Cultures in Early New England (New York: Oxford University Press, 2012).

9. Romero, Making War and Minting Christians, 84-89. 
Indian veterans. And no study yet puts the phenomenon of Indian soldiering into the context of colonial military history. Until recently, despite changing methodologies, most studies of Native Americans and cultural change in New England focused on Christianization and were based on sources generated by Protestant missionaries. Rarely consulted, colonial military records reveal a different story. Folding knowledge gleaned from military sources into existing ethnohistorical narratives about the Indian experience in the region provides important insight into the consequences of participation in the imperial wars for the region's Indians. ${ }^{10}$

Regardless of the loyal service of their men, however, most Indian communities in New England struggled for cultural and political autonomy. And far from showing any kind of pan-Indian unity, New England's Indian soldiers were agents of empire-conquering and killing other Natives with impunity for a European power. But they did so at great cost. It is clear from military records that Indian soldiers were more likely to experience torture at the hands of enemy Indians allied with the French than were white troops, and that they died far more often from contagious diseases in fetid camps than did whites. Many also came home with debilitating injuries that required long-term care or with diseases picked up in the army that spread to their home communities. Further, as a result of being captured, many experienced extended and often brutal captivity; some were even subjected to trans-Atlantic enslavement. Although it is fragmentary, and the findings presented here are tenuous, there is evidence that at least some Indian soldiers suffered psychological trauma as a result of wartime experiences.

\section{INDIANS, MICROBES, AND HIS MAJESTY'S \\ SERVICE: FORTS, CAMPS, AND DEATH}

Evidence points to the fact that, throughout the period under study, whenever Indians spent long periods in camps with Anglo-Americans, poor sanitation and crowding bred illness that caused them to die at a higher rate. During earlier colonial conflicts (King William's, Queen Anne's, and Governor Dummer's wars) Indians in the army died at a similar, or possibly

10. Silverman, Faith and Boundaries, 189, 225-26; Mandell, Bebind the Frontier, 130-32; Jean M. O’Brien, “'Divorced' from the Land: Resistance and Survival of Indian Women in Eighteenth Century New England,” in Colin G. Calloway, ed., After King Philip's War: Presence and Persistence in Indian New England (Hanover, N.H.: University Press of New England, 1997), 153-55; Den Ouden, Beyond Conquest, 174-77. 
even lower rate. But starting in the 1740s Indians' military experience came to more closely resemble that of white New Englanders. Indians served alongside whites in standard provincial infantry companies instead of allIndian ranger companies. In King George's War and especially during the French and Indian War, provincial companies were often stationed for months at a time in densely packed campsites or forts with thousands of other troops. Crowded and notorious for poor sanitation and hygiene, eighteenth-century military camps teemed with disease-typhus, smallpox, and other illnesses were common in encampments, but dysentery, spread through contaminated food and water, was particularly deadly. Combat fatalities aside, Fred Anderson calculated that, given these circumstances, soldiers died at a rate four times higher than they did in their home communities. ${ }^{11}$

Until King George's War, disease was probably less an issue for Indians in the army than it was for whites. In earlier conflicts, all-Indian units were highly mobile, ranging in small groups across extended areas, not spending months in tightly packed, unsanitary forts. Indian units wisely camped separately, away from the bulk of colonial forces, perhaps more for cultural reasons. Wampanoag and Nauset Indian companies did this in Maine in 1690 when on campaign with colonial troops led by Benjamin Church. The Indian ranger company led by John Gorham also camped outside the walls of Annapolis Royal in Nova Scotia in 1744, far from Anglo-American troops in the garrison. ${ }^{12}$ But once most New England Indian soldiers became members of provincial companies, mixed into regiments and serving in the same capacities as Anglo soldiers, and living among them in densely populated encampments, they were exposed to microbes that proved far more deadly to them.

Perhaps the strongest evidence for Indians being especially vulnerable to camp sicknesses comes from King George's War, particularly sources related to the occupation of Louisburg in 1745 . Disease hardly affected the New

11. Anderson, A People's Army, 95-102; Kathleen M. Brown, Foul Bodies: Cleanliness in Early America (New Haven: Yale University Press, 2009), 174-75; Gerald N. Grob, The Deadly Truth: A History of Disease in America (Cambridge: Harvard University Press, 2002), 90-92; Romance, Remedies, and Revolution: The Journals of Dr. Elibu Ashley of Deerfield, Massachusetts, 1773-1775, ed. Amelia F. Miller and A. R. Riggs (Amherst: University of Massachusetts Press, 2007), 21, 246-47.

12. Thomas Church, The History of Philip's War, Commonly Called the Great Indian War of 1675 and 1676, Also, of the French and Indian Wars at the Eastward . . . ed. Samuel G. Drake (Exeter, N.H.: J. \& B. Williams, 1843), 193-94; Boston News-Letter, November 11, 1744. 
England forces that captured the French fortress in the summer of 1745. But afterward, in the fall and winter, illness infected the troops assigned to garrison the city. This suggests Algonquians from New England were still highly susceptible to Old World pathogens. Records of Captain Adonijah Fitch's company from Connecticut, stationed in the garrison, supports Stiles's claims about Connecticut Indians dying in high numbers. Fourteen Mohegan and Pequot men were in the company. Eight (57 percent) died in two clusters, suggesting contagious disease. Six died between 10 December and 11 January, a period when they were not engaged in combat operations. Other sources confirm that this was a time of sickness and death in the garrison. Samuel Chapman's company, from the same regiment, was stationed at Louisburg during this same time. Two of the three Indians in that company, Jeremiah Toto and "Nymrod, Indian," died that same month. Two months later, in March 1746, another two Indians from Fitch's company succumbed. At the end of the war, the Reverend Jacob Johnson of Groton recorded the effect these deaths had on the Mashantucket Pequots. He noted many widows in the community "who [had] lost their husbands in the late war." A later historian of the Mashantuckets noted that, like the Nauset communities on the outer Cape, "so many of them were killed in battle and died of disease, that the women and children at home were wellnigh reduced to starvation."13 Stiles noted that though four decades earlier a hundred Indians had resided in East Haven, Connecticut, by 1762 only about half that number remained. He attributed a significant portion of that decline to losses resulting from the Louisburg expedition. ${ }^{14}$

13. Order dated Louisburg, March 11, 1746, in "Pepperell Manuscripts," New England Historical and Genealogical Register (hereafter cited as NEHGR) 19 (1865): 141-48, 222-30; lists of the ninth and tenth companies of the Connecticut contingent at Louisburg, Commissary's Book, 1745-1746, French and Indian War Papers, CHS. An earlier roster of Fitch's company (the tenth company) lists twenty Indians, not fourteen; Indian Papers, 1st ser., 2:237-38, Connecticut State Archives Collection, Connecticut State Archives, Hartford; Richard A. Wheeler, The Pequot Indians: An Historical Sketch (Westerly, R.I., 1887), 20. For Indian susceptibility to European diseases, see Albert W. Crosby Jr., "Virgin Soil Epidemics as a Factor in the Aboriginal Depopulation in America," William and Mary Quarterly 33 (April 1976): 289-99; David S. Jones, "Virgin Soils Revisited," William and Mary Quarterly 60, no. 4 (2003): 703-42; Dean R. Snow and Kim M. Lanphear, "European Contact and Indian Depopulation in the Northeast: The Timing of the First Epidemics," Ethnohistory 35, no. 1 (1988): 15-33; Ann Ramenofsky, "Native American Disease History: Past, Present and Future Directions," World Archaeology 35, no. 2 (2003): 241-57; and Russell Thornton, American Indian Holocaust and Survival: A Population History since 1492 (Norman: University of Oklahoma Press, 1990).

14. Stiles, Extracts from the Itineraries, 134. 
Like their Connecticut brethren, Massachusetts Indians in the Louisburg garrison also suffered high mortality rates. The Sixth Massachusetts Regiment, recruited from Bristol County and commanded by Colonel Sylvester Richmond, contained dozens of Natives. Many become ill and died. Stephen Williams, the regimental chaplain, ministered to the sick and dying. His diary entry from September 1745 is typical: "Last night Sergt. Chattuck of the Collonells company, and one Barlow, of Capt. Hathaways company, and an Indian of capt: Lawrences company dyd." A few days later he saw a Wampanoag named John Mommopuit die. Things only got worse; conditions were so bad that white and Indian troops began to mutiny. Promises of wage increases by Governor William Shirley himself combined with threats of severe punishment quelled mass desertions, but disease continued to plague the garrison. Williams reported visiting his regiment's hospital on November 9, 1745. Conditions were still grim. He recorded "some in that House are very low—an Indian of Colonel Sylvester Richmonds company dyd." The next day he reported that "one Slate an Indian of Colonel Bradstreets company" passed away. In the next few days, along with reporting Anglo-Americans ill and dying, he continued to note Indians as prevalent among the sick. In perhaps the most heart-wrenching incident, Williams reported on November 18, "this morning, John Sassimon, an Indian of Capt. Hathaways company-was found dead, in the street, he went out 'tis thought in a distraction-having been ill—an awful providence." Dudley Bradstreet, a Massachusetts lieutenant, also kept a diary at Louisburg. He was himself taken ill in September. In mid-November, when he was finally strong enough to venture out into the camp again, he was astonished by what greeted him. "I went into the Burying yard," he wrote, " $\&$ there beheld a Melancholy sight: hundreds of new graves." ${ }^{15}$

Throughout King George's War, whenever they were encamped for prolonged periods, Indians in the New England forces continued to die at higher rates than Anglo-Americans. Thousands of troops were mobilized to invade Canada in 1746 before the expedition was canceled and the force disbanded-except for one battalion diverted to Nova Scotia to aid in combatting an Acadian-Mi'kmaq insurgency against British rule. Captain

15. Charles Hudson, "Louisburg Soldiers," NEHGR 25 (1871): 249-70; H. Hamilton Hurd, History of Bristol County, Massachusetts . . (Philadelphia: J. W. Lewis, 1883), 223; anonymous journal, September 6-18, 1745, Louisburg Papers (microfilm), MHS; Louisburg Journals, 1745, ed. Louis Effingham De Forest (New York: Society of Colonial Wars, 1932), 136-67; Diary Kept by Lieut. Dudley Bradstreet of Groton, Mass., during the Siege of Louisburg, April, 1745-January, 1746, ed. Samuel A. Green (Cambridge, Mass.: J. Wilson, 1897), 29. 
Elisha Doane's company from southeastern Massachusetts was part of that force. Sixty-five of his privates were Anglo-American and twenty-one were Wampanoag. Along with other troops, they were camped for weeks at Castle William in Boston Harbor awaiting embarkation. This proved deadly for the company's Indians. More died from illness once in Nova Scotia. In October 1747 the company's final muster roll was drawn up. It contained fifty-three Anglo-American privates and just eleven Indians. ${ }^{16}$ Fifty-three percent of the Wampanoags died compared to 18 percent of Anglos. The Indian mortality rate was three times higher.

Like all British military forces that took part, New England troops that participated in campaigns in the Caribbean during the era suffered even higher death tolls than those previously cited because of lack of previous exposure to tropical diseases. But, once again, Indians died at higher rates. Almost all the Wampanoag and Nipmuc soldiers in the campaign to the West Indies to capture Spanish-controlled Cartagena between 1740 and 1742 died from sickness. The muster roll of Captain John Winslow's company in the Third Battalion of His Majesty's American Regiment of Foot shows twenty-four of the fifty-five privates, almost half the men, were Indians from Massachusetts. While they were quartered in Jamaica, between April 1 and June 24, 1741, a fever spread through the company, claiming the lives of over one-third of the men. Among others, this included Moses Ralph, a Nauset, who died on April 29, Joseph Cognehew of Mashpee, who died two days later, and Hezekiah Zachary of Herring Pond, who passed the next day. Joseph Coquish from the Freetown-Watuppa reserve perished along with Benjamin Tray of Natick on May 10, and Timothy Quack, probably from Punkapaug, died June 2. Nearly half the unit's Indians perished in the outbreak. Almost as appalling is the fact that 29 percent of AngloAmericans did as well. The British forces sent to attack Havana, Cuba, twenty years later, in 1762, were also devastated, particularly by malaria. Large numbers of Connecticut and Rhode Island Indians took part in the expedition against the Spanish, but, thanks to illness, most never returned. For example, almost half the sixty-three men in Giles Russell's company in the Rhode Island contingent died. But again, Indians had it worse. The unit lost 40 percent of its white troops, but 67 percent of its Indian members succumbed. Only eight of twenty-four survived. ${ }^{17}$

16. Muster roll, Elisha Doane's company, June 8-August 24, 1746, and October 1747, Suffolk Files (no. 65640), Mass. State Archives.

17. Walter K. Watkins, "Massachusetts in the Expedition under Admiral Vernon 1740-1 to the West Indies," and "The Capture of Havana in 1762," in The YearBook of the Society of Colonial Wars in the Commonwealth of Massachusetts for 1899 
Indian troops also brought death home. Sick soldiers returning from the front sometimes infected their families and villages. Jacob Simon, a Mashpee Wampanoag in Captain Sylvanus Bourne's company in 1758, "came Home Infected with the Smallpox and soon after His Return Broke Out with that Distemper" and "Greatly Suffered," wrote his commander. Gideon Hawley, a missionary, noted Simon's returning to Mashpee on November 19 and feared the worst when he showed signs of the disease. Captain Bourne's father, one of the provincial guardians appointed to oversee tribal affairs, saw to it that Simon received medical treatment, but he reported that "Jacob Died of said Sickness." Other Mashpees were soon dying in the wake of Simon's return. In a scene reminiscent of John Sassimon's death thirteen years earlier, Peter Isaac, another returning veteran, ran out into the snow delirious with fever and died on November 29. Jacob Richards died two days later, and Joe Orchard the next day. Two of Jacob Nautompom's children and an unnamed child of Benjamin Mingo's were soon dead of the illness. Out of fear of contracting the disease, one aged couple confined themselves to their wigwam. They survived, but other Mashpees continued to die through the new year. ${ }^{18}$

Other settlement Indians in southern New England also lost many of their men to war and disease. Natick was hit particularly hard. Jean O'Brien identified thirty Natick men serving in the army during the late imperial wars, a time when the population declined precipitously. Fifty members of the community died between 1744 and 1746 from an illness that Mandell concludes was "probably brought back from military service by soldiers." By the end of the war Natick women outnumbered men two to one, as at Herring Pond, Potanomecut, and Niantic. Conditions were similar in the next war. In late 1759 Natick men, like returning Mashpees the previous

(Boston: Society of Colonials Wars, 1899), 65-124, 125-68; E. Alfred Jones, "The American Regiment in the Carthagena [sic] Expedition," Virginia Magazine of History and Biography 30, no. 1 (1922): 1-20; J.D.C. Jr., "Captain Russell's Company 1762," NEHGR 14 (1860): 56-57; Albert C. Bates, ed., The Two Putnams: Israel and Rufus in the Havana Expedition 1762 . . (Hartford: Connecticut Historical Society, 1931), 49-53; Howard M. Chapin, ed., Rhode Island in the Colonial Wars: A List of Rhode Island Soldiers and Sailors in the Old French and Indian War, 1755-1762 (Providence, R.I., 1918), 100, 126.

18. Memorial of Sylvanus Bourne and Edward Bacon Esqs. to Governor Thomas Pownall, June 6, 1759, Mass. Archives, 33:108; entries for November 19, 23-24, and December 18, 25, and 27, 1758, Gideon Hawley Diaries (microfilm), MHS. 
year, brought home an illness that scythed through the population. The missionary Stephen Badger recalled the devastation wrought by the epidemic: "in the several wars that took place between 1754 and 1760, many of them engaged in the service; not a small number died while in it; others returned home, and brought contagious sickness with them; it spread very fast, and carried off some whole families. This was in 1759. In the space of about three months, more than twenty of them died, all of the same disorder, which was a putrid fever; it carried them off in [only] a few days." Badger noted that only one local Anglo-American died from the fever, but for Indians it was "a time of sickness and great mortality." ${ }^{19}$

\section{BROKEN BONES, BROKEN BODIES, BROKEN RESERVATIONS}

Some Indians returned home severely injured from the colonial wars. Caring for them placed a burden on Indian communities. Medical accounts from King George's War show Indian soldiers treated for various injuries, ranging from minor to disabling. Dr. Israel Ashley tended Massachusetts provincial troops in Nova Scotia in 1746 and 1747. He bled and prescribed medicines for an Indian soldier listed in his accounts as "Abraham, Indian"-probably Abraham Speen of Natick. The injury was serious; Ashley recorded dressing a wound on Speen's arm fifteen times. Another account records the surgeon Benoni Sweat setting broken bones for fifteen soldiers on the same deployment. Injuries included broken ankles, shoulders, and hands and cracked ribs. Six of the men were Indians, including Philip Call, from Cape Cod, Sweat's most challenging case. Sweat had to set Call's severely broken collarbone twice. Zachariah Tom, a Nipmuc from the Hassanamisco Reservation in Grafton, Massachusetts, was so sick that Dr. John Wilson of Sherborn either visited or prescribed medicine for him thirty times over thirty-two days in August and September 1747. ${ }^{20}$ Tom left the army sick and in debt: his doctor bills were more than twenty-two pounds, which far exceeded what he earned on the deployment.

On behalf of disabled Indians, reservation overseers or local selectmen

19. O'Brien, Dispossession by Degrees; Mandell, Behind the Frontier, 118, 128-29; Stephen Badger, "Historical and Characteristic Traits of the American Indians in General, and Those of Natick in Particular ...," in Collections of the Massachusetts Historical Society for the Year 1798 (Boston: Samuel Hall, 1798), 40-41.

20. Account of Israel Ashley, Westfield, Mass., February 5, 1747, Suffolk Files (no. 65640); Account of Expedition to Canada to Estate of Dr. Benoni Sweat, Boston, June 7, 1748, Suffolk Files (no. 65640); Zachariah Tom to John Wilson, Sherborn, March 31, 1748, Suffolk Files (no. 65640), all Mass. State Archives. 
applied for relief from the mounting expenses they incurred caring for injured and indigent Indian veterans. Wounded and disabled veterans also sometimes fell into debt paying for treatment or extended care, straining meager budgets and sapping tribal and reservation funds. Some were forced to sell tribal land or indenture themselves or family members to meet debt obligations. Some veterans appealed directly to the governor's council or the provincial assembly for relief, to varying degrees of success. William Simons, a Wampanoag preacher from Teticut (Middleboro) and an experienced soldier, lost his leg in the service and received a pension in 1752 . Daniel Job lost his sight in the military. He returned to Mashpee and applied for aid to compensate another Indian veteran, Daniel Sunkasun, who was caring for him. Twenty-four-year-old Joseph Pognit was paralyzed as a result of a wound received in a skirmish with the Mi'kmaq on the Petitcodiac River during the expulsion of the Acadians in September 1755. $\mathrm{He}$ and his wife, Ziporah, fell deeply into debt paying for medical care. They sold their land in Natick to pay their bills. ${ }^{21}$

\section{NARRATIVES OF CAPTIVITY}

While historians have noted the effects of death and disease resulting from military service on New England Indians, few have addressed captivity. Like English soldiers and civilians, Indians from southern New England fighting in the late colonial wars were captured and sometimes adopted by Indians allied with the French. What this experience was like for them compared to that of English captives has yet to be examined. Captivity is well studied by scholars because of numerous narratives written by redeemed captives that provide rich descriptions of intercultural encounters and serve as

21. Accounts of Stephen David, Indian, April 23, 1754, Mass. Archives, 33:94-95; Petition of Jonathan Woods and James Keith, Bridgewater [Mass.], April 1754, Mass. Archives, 33:118-19; The Acts and Resolves, Public and Private, of the Province of Massachusetts Bay . . , 19 vols. (Boston: Wright \& Potter, 1867-1918) (hereafter cited as Acts and Resolves), 15:153; 9:439-40; Journals of the House of Representatives, vol. 1, 1715-1717 (Boston: Massachusetts Historical Society, 1919), 198, 208; Petitions of William Jeffery [various dates, 1724-1726], Mass. Archives, 31:112, 31:154-55, 31:346-47; Petitions of John Simons, 1752, Mass. Archives, 32:318, 419-21; Mandell, Behind the Frontier, 128-131; "A List of the Men Missing and of the Wounded Returned of Major Fry's Party, since the Engagement at [Petitcodiac] on the 2nd of September [1755]," Boston Gazette or Weekly Journal, October 6, 1755; Petition of Joseph and Ziporah Pogenit, July 10, 1756, Mass. Archives, 32:708-9. 
important, albeit problematic, ethnographic accounts of indigenous culture. ${ }^{22}$ But captive Indian soldiers are rarely accounted for. Though no captivity narratives written by Native soldiers exist, pension requests by former Indian captives do survive. They raise important questions about citizenship, race, and identity and about the responsibility of provincial governments to Native subjects.

On July 6, 1749, the Boston News-Letter printed a letter detailing efforts to redeem Englishmen and Englishwomen residing in Canada who had been captured during King George's War. A few lived among the French, while most were held in various Indian communities. Tacked on was the notice: "We also hear, that there are nine Cape Cod Indians at Canada, five of which were taken at Annapolis Royal, who were under the Command of Col. Gorham in the year 1745; some of them are sold as Slaves to the Indians; that they are very desirous of being redeemed." The fate of six of these Wampanoag soldiers can be ascertained from surviving records. Two started out as "slaves" but in time were fully adopted into the communities where they were held. Rather than return to New England, Isaac Peck chose to remain among the Saint Francis Abenakis, where he converted to Catholicism and married. Probably from Mashpee, Philip Will, only fourteen years old when captured in 1745 , had grown up an indentured servant in an English household. Adopted by the Androscoggins (an eastern Abenaki band), in time he became the band's sachem. Also adopted by the Abenakis were two other captive Mashpees, Webquish and Caleb Popmonet. Jacob Chammock, from Herring Pond, was held in Quebec and later released.23

Perhaps the best-documented Indian captive taken in King George's War was Peter Dogamus of Yarmouth, Massachusetts. The great-grandson of

22. Mandell, Behind the Frontier, 128-31; see also O'Brien, Dispossession by Degrees; Peter J. Way, "The Cutting Edge of Culture: British Soldiers Encounter Native Americans in the French and Indian War," in Martin Daunton and Rick Halpern, eds., Empire and Others: British Encounters with Indigenous Peoples, 16001850 (Philadelphia: University of Pennsylvania Press, 1999), 123-42; Stephen Brumwell, Redcoats: The British Soldier and War in the Americas, 1755-1763 (New York: Cambridge University Press, 2002), 66, 162, 168-72.

23. Emma Lewis Coleman, New England Captives Carried to Canada, 2 vols. (1897; repr., Bowie, Md.: Heritage Books, 2008), 2:402; George A. Wheeler and Henry W. Wheeler, History of Brunswick, Topsham, and Harpswell (Boston: Alfred Mudge \& Son, 1878), 3; "Treaty with the Eastern Indians at Falmouth, 1749" (September 27-October 16, 1749), in Collections of the Maine Historical Society 4 (1856): 145-67. 
the Nauset grand sachem Mattaquason and more than fifty years old in the fall of 1744 when he enlisted, Dogamus was a veteran of two previous wars. In May 1745 approximately five hundred French soldiers, Acadian militia, and their Mi'kmaq allies attacked the English base on Goat Island, opposite Annapolis Royal in Nova Scotia. They captured the Indian rangers as well as the white crewmen from two supply schooners. Over the next two months, his captors took Dogamus and his fellow prisoners on a sixhundred-mile trek to Quebec. ${ }^{24}$ The rangers were routinely beaten. Some were tortured and several killed. Upon reaching the capital of New France, the remaining captured Native soldiers were dispersed into Iroquois, Huron, and Abenaki communities. For the next five years Dogamus lived as a slave among the Kahnawake Mohawks, near Montreal. ${ }^{25} \mathrm{He}$ was treated harshly, like many captive Indian soldiers from New England. As I've noted, however, circumstances varied. In contrast, Peck and Will were treated comparatively well and became fully integrated into the Abenaki communities where they were held.

These captive Indian soldiers may have been gone, but they were not

24. Petition of Peter Dogamus of Yarmouth in the County of Barnstable, Indian man, January 10, 1750, Mass. Archives, 73:744; The Journal of Captain William Pote, Jr. during His Captivity in the French and Indian War from May 1745 to August 1747 (New York: Dodd, Mead, 1896), 59-60, 62-63, 86. Deposition of John Cousins, April 21, 1720 (no. 15919); Deposition of Jeremiah Meneikish, January 20, 1719-20 (no. 13717); Mortgage of Dogamus, Stephen and Richard, August 19, 1693 (no. 3297), all Suffolk Files, Mass. State Archives; Acts and Resolves, 13:504; 14:477, 600; Muster roll, company of Richard Bourne, 1724, Mass. Archives, 91:139-41; Muster roll, company of William Kennedy, 1725, Mass. Archives, 91:178-80; Warren Sears Nickerson, "Indian Rangers-Exploits of a Cape Cod Indian at Louisbourg, 1745," in Delores Bird Carpenter, ed., Early Encounters: Native Americans and Europeans in New England from the Papers of W. Sears Nickerson (East Lansing: Michigan State University Press, 1994), 130-33; Collection de manuscrits contenant lettres, mémoires, et autre documents historiques relatifs à la Nouvelle-France, recueillis aux archives de la province de Québec, ou copiés à l'étranger, 4 vols. (Quebec: Imprimerie A. Coté and Co., 1884), 3:488-89, 491.

25. In my earlier article, "Savages in the Service of Empire: Native American Soldiers in Gorham's Rangers, 1744-1762," New England Quarterly 85, no. 3 (2012): 404, I mentioned that Dogamus was probably held at the Huron village of Lorrette. A document has come to light, however, mentioning him being held by "the Iroquois Sault-Saint-Louis" or the Kahnawake (Caughnawauge) Mohawks, near Montreal. See "Procès-verbal concernant la restitution de prisonniers anglais ... ," Montreal, June 26, 1750, Centre des Archives d'Outre-Mer (Aix-enProvence, France), vol. 96 (copy in Série C11A, Correspondance générale, Canada, R11577-4-2-F, Archives Canada). Thanks to Zydric Purdy for this reference. 
forgotten. By January 1749 dozens of petitions and requests from the captured rangers' families, none of which survive, unfortunately, spurred both Crown and province to take a greater interest in the plight of Indians languishing in Canada. The provincial committee that investigated the matter recommended that the lieutenant governor declare to the governor of Canada that "the Indians Captivated from Nova Scotia in the late War, are Subjects of the King of Great Britain having been born within this province." Therefore, they should "equally enjoy the privileges" thereof, and the French should "forthwith give Liberty, and Signifie it to any and every Indian (that may still remain in Canada Captivated as aforesaid) his leave for them to return to this Province and by no means to detain them against their wills" or continue to allow them to be "sold for Slaves." ${ }^{66}$ Agreeing to an exchange, French officials began locating Indian captives.

Despite their efforts, the only one who could be located, and who was willing to return, was Peter Dogamus. Along with Anglo-American captives desiring repatriation, he was taken to Fort Saint-Frederick (later Crown Point) in July 1750 and exchanged for French prisoners held by the English. He made his way back to New England and in January 1751 was in Barnstable seeking assistance. Then more than sixty years old, Dogamus requested a pension from the province for his forty-plus years of service and for the suffering he had endured as a captive. In his request, penned on his behalf by Colonel Melatiah Bourne, he was described as having "grown old \& spent great parts of his life in the Service." Claiming he was "not able to support himself," he asked for an allowance. Hardly treated like a subject of the king or an inhabitant of the province entitled to certain rights, Dogamus was granted no back pay for his time in captivity, and he was awarded only six pounds per annum-about a quarter to a third of what a soldier earned on a typical deployment. ${ }^{27}$

As they had been in King George's War, during the French and Indian War many Indian soldiers from New England were captured. Again, some former Indian captives petitioned their governors or legislatures for pensions or relief. Their experiences varied considerably. In 1755 Nanticoke and Delaware Indians fighting for the French captured Eleazer Pognit, of Natick,

26. Thomas Berry to Spencer Phipps, January 1749, Mass. Archives, 31:686, 692; Petition of John Gorham, Esq., to the Governor and General Court of Massachusetts, Boston, April 5, 1749, Mass. Archives, 73:393-99.

27. Petition of Peter Dogamus, Mass. Archives, 73:744. 
after he deserted the regiment he was serving with at Fort Oswego on Lake Ontario. Now far from the tribe's traditional homelands in Delaware and Maryland, his Nanticoke captors had been driven by English encroachment onto the upper Susquehanna River on the border of Iroquoia, and some moved into Canada. The refugees forcibly adopted Pognit into their band and he lived for months with them among French-allied Senecas. He participated in raids against British-American settlements in the Virginia backcountry (which left dozens dead), recalling, "when I went out [with them] I was painted \& my hair cut as theirs was." He escaped and made his way back to New England. ${ }^{28}$

Numerous Native soldiers were taken prisoner at the capitulation of Fort William Henry in 1757. Some were never heard from again, either dying in captivity or integrating into Indian communities far from their homes, although some returned to New England in subsequent years. Some were Narragansetts, but most were Wampanoags serving in the Massachusetts provincial companies commanded by Samuel Nichols Nelson, Joseph Ingersoll, and, as mentioned earlier, Peter West. Joseph Joseph of Wareham, from Nelson's company, was taken to Montreal after the capitulation and, according to his pension request, written by an Anglo-American officer on his behalf, "to an Indian town \& there given to an Indian with whome I lived until the surrender of Montreal [in 1760]." He claimed to have "suffered many $\&$ great hardships while in his captivity," in addition to the "loss of time in the prime of his life." He returned home "almost naked \& [had] nothing to clothe himself or support him but only his labor \& the wages due for his service." For his three years in captivity, he received only eight pounds in total. On a typical nine-month deployment, privates usually earned around sixteen pounds. John Pequet of Dartmouth, from Ingersoll's company, described himself as "carried away Captive by the Indians" to Canada and there, like Dogamus had been earlier, "confined to hard Labour \& Cruell Suffering." Once back in New England, he too was destitute and petitioned for an allowance. After three years in captivity the Wampanoag soldier Aaron Conkaney of Bridgewater was released in a prisoner exchange in 1760. Deborah Bristol of Herring Pond applied for relief

28. Pognit's participation in raids in Virginia was controversial. On April 14, 1756, he was examined by Jonathan Cushing, a member of a committee of the Massachusetts House of Representatives that was formed to investigate his activities; Jonathan Cushing, Examination of Eleazer Pognit, April 14, 1756, Mass. Archives, 32:717; C. A. Weslager, Delaware's Forgotten Folk: The Story of the Moors and Nanticokes (1943; repr., Philadelphia: University of Pennsylvania Press, 2006), $60,73,118$. 
after she received news in 1762 that her captured husband, James Bristol, had been taken as a servant or slave to France, where he died. ${ }^{29}$

The experiences of two Wampanoag brothers from Martha's Vineyard, Joseph and Philip Metack, who were taken at the capitulation in 1757, are particularly well documented. Philip's pension request stated:

The Indian Enemy (Countenanced by the French) were allowd, to Enter the fort and Brestwork Contrary to agreement; Seize Captives and Carry away your poor petitioner with his Brother and many more Indians; and all the Black people and as many white into a disagreeable Captivity, where [he] was Continued in Servitude with an Indian master, undergoing many hardships, besides being stripped of his liberty at the risk of his life; By runing from a party of Indians and four french men that marched from Oswegocha; Towards Fort Stanwix; in order to make Discoverys, and Take prisoners Scalps \&c: at which Time [he] ran from them to the English Camp; at the Oneida Station; and from thence was Conveyd, to mount Johnson; from thence to Albany; from thence marchd to Roxbury [Massachusetts] where [he] arived at Mr Joseph Ruggles' on the 17th Day of Dec[embe]r after the Loss of much Time and undergoing many hardships and Difficultys... . [He] prays that [you] would Take his Case into your wise and Compassionate Consideration and make him such allowance for Time and sufferings as in your wisdom shall seem meet. $^{30}$

His brother Joseph had similar experiences following the surrender. His remarkable petition from several years later reads:

he was Included in the Capitulation yet he was Carried away Captive by the Indians, and for three years togeather, had one Cruel and hard Master. ... he once Attempted to make his Escape but was Discovered, this would have Cost him his Life had not a French Priest Interposed, but not to Trouble you with a Long detail with the Many and Greivious hardships he underwent in his long Captivity he at

29. Petition of Joseph Joseph, Mass. Archives, 79:564; Petition of Nathan Joseph, Mass. Archives, 84:302-20; Petition of John Pequet, Mass. Archives, 33:194-94a; Petition of Aaron Conkaney, Mass. Archives, 84:317; Acts and Resolves, 16:485; Petition of Deborah Bristow, Mass. Archives, 80:213-13a. A typical provincial muster roll for a deployment from 1756 shows officers earning over forty pounds, whereas enlisted men generally earned between thirteen and sixteen pounds; Muster roll, company of Captain Samuel Knowles, April 1758, Mass. Archives, 97:13.

30. Petition of Philip Metack, 1761, Mass. Archives, 33:73. Thanks to Andrew Pierce for the references to the Metacks' petitions. 
Last when Genl Amharst was within about Thirty Miles of the Indian Village where his Master lived he then made his Escape, and got Safe to the Army, and Inlisted Imediately into the Service under the Comand of Capt. Dunlap and was discharged at Crown Point in Decr Last and Returned home. ${ }^{31}$

Philip and Joseph Metack received the very low amounts of five pounds and two pounds, respectively, from the province, probably because, as members of a reservation community, they could draw on tribal resources through their province-appointed guardians. In any case, it is clear that most captive Indian soldiers suffered in captivity yet received only modest compensation from provincial governments.

Captives suffered mentally as well, although the evidence is thin for the effects of psychological trauma on prisoners. Father Pierre-Joseph-Antoine Roubaud, a Jesuit missionary accompanying Abenaki warriors on the French expedition to capture Fort William Henry, recorded a revealing incident before the siege about the psychological state of an adopted New England Indian soldier. A dispute between allied warriors over the division of war captives escalated into a brawl. The missionary calmed the situation, but one Abenaki abruptly attacked an Iroquois companion, almost killing him. He was described by Roubaud as a "Moraigan naturalized and adopted into the Abenakis Tribe." Moraigan, sometimes Maringham, was a term used by the French and their Indian allies to describe southern New England Algonquians irrespective of tribe. Roubaud and others wrestled the Moraigan to the ground. The Jesuit attempted to quell the man's rage "by dint of shaking the Abenaki." Roubaud observed, "he at last perceived that he was being shaken; then he turned his head, but it was only with much difficulty that he recognized me." Roubaud noted, "he needed a few moments to come to himself." Did the dispensation of captives trigger an emotional response- a flashback to his own capture? For all we know, this could have been the now-twenty-six-year-old Philip Will, adopted a decade earlier by the Androscoggins. Or it could have been any of a number of New England Algonquians captured in the late colonial wars. That he seemed confused and unsure of where he was and that he lashed out should not surprise us. Although historians have only just begun to address how

31. Petition of Joseph Metack, 1761, Mass. Archives, 33:161-62, 133:224. Again, thanks to Andrew Pierce for citations; Joseph's account is corroborated by a deposition taken by Sir William Johnson, "Information of Jonathan, alias Martin, lately from Canada," Fort Johnson, June 4, 1760, Amherst Papers, War Office (Great Britain), 34-43, 16-19. 
stress and trauma manifest themselves in different cultural and historical settings, this incident speaks to the profound psychological dislocation that plagued some veterans. ${ }^{32}$

Not all captives were adopted. In particular, New England Indians captured fighting in the British army ranger corps during the French and Indian War often met with gruesome torture and death—in keeping with mourning war traditions common among northeastern groups, particularly French-allied Iroquois. Combining French and English military sources reveals attitudes toward them, their treatment, and, in some cases, descriptions of their deaths. Louis Antoine de Bougainville, a high-ranking French officer, reported in a journal he kept on July 6, 1757, that a combined force of French, Abenakis, and Iroquois captured two "Mahicans" and an Englishmen - the same three men reported missing in that area by Connecticut's Sergeant Jabez Fitch in his diary. They were part of a scouting party from Israel Putnam's Connecticut ranger company. Bougainville reported, "The Indians brought two of them to me and tore the other apart,

32. Letter from Father *** [Pierre-Joseph-Antoine Roubaud], Missionary to the Abenakis, Saint Francis, October 21, 1757, in Reuben Gold Thwaites, ed., The Jesuit Relations and Allied Documents, Travels and Explorations of the Jesuit Missionaries in New France, 1610-1791, vol. 60 (Cleveland: Burrows Brothers Co., 1900), 161. The classic work on captivity is James Axtell's The Invasion Within: The Contest of Cultures in Colonial North America (New York: Oxford University Press, 1985), 271-328. Historians have only begun to discuss the possibility that people who experienced captivity may have suffered from post-traumatic stress disorder (PTSD). Some psychologists have suggested that PTSD is a modern Western culture-bound disorder, but evidence suggests cross-cultural as well as cross-temporal validity. See Michael R. Trimble, "Post-Traumatic Stress Disorder: History of a Concept," in C. R. Figley, ed., Trauma and Its Wake: The Study and Treatment of Post-Traumatic Stress Disorder (New York: Brunner/Mazel, 1985), 5-14; Spero Manson et al., "Wounded Spirits, Ailing Hearts: PTSD and Related Disorders among American Indians," in Anthony J. Marsella, Matthew J. Friedman, Ellen T. Gerrity, and Raymond M. Scurfield, eds., Ethnocultural Aspects of Posttraumatic Stress Disorder: Issues, Research, and Clinical Application (Washington, D.C.: American Psychological Association, 1996); Marc-Antoine Crocq and Louis Crocq, "From Shell Shock and War Neurosis to Posttraumatic Stress Disorder: A History of Psychotraumatology," Dialogues in Clinical Neuroscience 2, no. 1 (2000): 47-55; D. E. Hinton and R. Lewis-Fernández, "The Cross-Cultural Validity of Posttraumatic Stress Disorder: Implications for DSM-5," Depression and Anxiety 28, no. 9 (2011): 783-801. 
and as he was good, they ate him." Fitch knew the man who was "torn apart"- Henry Shuntup, a Mohegan. Fitch reported "they Found Henry Shuntup in the woods Kild \& Scalpt[,] His throat Cut \& his Brest Cut open \& Hart out \& Gon[,] a large Pies of wood Left in the Plais of it." Though of small consolation to Shuntup, his family, and those who knew him, the death he was given by the Iroquois was that befitting an honorable warrior. Carefully scripted behavior was expected of a captive, according to Iroquois custom. Shuntup had either displayed great bravery before being captured or, more probably, remained stoic and defiant in the face of torture and death. Either way, his captors, according to Bougainville, were impressed, deeming that "he was good." That his heart was consumed in an act of ritualized cannibalism, an Iroquois war custom, was a sign of their respect for Shuntup and born of a desire to absorb the Mohegan's spiritual potency - the manitou possessed by a renowned warrior. The Iroquois deemed the other captured Connecticut Indian ranger, whom Fitch identified as Jabez Jones, "unappetizing" because he had apparently shown fear or begged for mercy. Bougainville in fact noted that, of the three, it was Jones who cracked and gave up intelligence about British troop strength and movements. Jones and the other captive, an Irishman named John Kennedy (who was severely wounded) were probably unceremoniously killed, neither accorded the "honors" bestowed on Shuntup. ${ }^{33}$

Just a week after Shuntup's death, an unnamed Indian soldier fighting for the British suffered equally brutal punishment at the hands of his Abenaki and Ottawa captors at a French encampment near Fort William Henry, according to Father Roubaud. It was possibly Jones, or, more likely, another Mohegan from Putnam's company captured while running dispatches between Fort Edward and Fort William Henry before the capitulation on August 9. According to Roubaud, his captors tied him to a tree and taunted the man for days. Perhaps, if it was Jones, this might have been because they perceived him a coward. They beat him mercilessly, until, "by a blow, roughly dealt, one of his eyes was nearly torn from its socket." Roubaud claimed that "the proceeding shocked me," and, moved by pity, he "drove

33. Bougainville, Adventure in the Wilderness: The American Journals of Louis Antoine de Bougainville, 1756-1760, ed. Edward P. Hamilton (1964; repr., Norman: University of Oklahoma Press, 1990), 121-22; The Diary of Jabez Fitch, Jr., in the French and Indian War, 1757, ed. Richard A. Mason (Albany, N.Y.: Rogers Island Historical Association, 1966), 244-45. 
away all the spectators" and guarded the "Moraigon," imploring his captors to spare the man. It is unclear if he was successful. ${ }^{34}$

Though spared the torture and brutal murder visited on Shuntup and Jones, and the lengthy captivity in Canada experienced by the Metack brothers, two men from the Indian ranger companies in Rogers's ranger corps, a Stockbridge Mohican and a Mohegan from Connecticut, instead experienced a yearlong odyssey around the Atlantic. Pulled far from the borderlands where they were captured, they were cast into the (until recently) poorly understood North American indigenous slave trade that connected the pays d'en baut to French Caribbean plantations. According to recent work by the historian Brett Rushforth, a slave-centered war culture exchanged indigenous captives taken half a continent away, solidifying alliances between different groups of Natives and between Natives and the French. The two rangers were captured while patrolling near Lake George in spring 1758 by Indians allied with the French. Their captors sold them to the captain of a French man-of-war anchored at Quebec. The pair was transported thousands of miles to the Caribbean and sold as slaves to the owner of a sugar plantation in the French colony of Saint Domingue (current-day Haiti). They toiled alongside the plantation's African slaves for months in the tropical heat, which they characterized as "extreme hard Labour," and lived on a "slender Diet." A sympathetic Spaniard (who spoke English) helped them escape. Stealing machetes and a gun, they fled into the jungle and made their way over the Massif du Nord mountains (Cordillera Central in Spanish) toward San Fernando de Monte Cristi, in the Spanish colony of Santo Domingo in the eastern portion of Hispaniola. The trek took two weeks, but, once in Monte Cristi, they secured passage on a British merchant ship (probably a smuggler carrying contraband molasses) bound for New London, Connecticut. They arrived back in New England a year after being captured. ${ }^{35}$

\section{WINNERS AND LOSERS}

New England's Indians in the eighteenth century assumed that their military service would give them political capital in negotiations with provincial

34. Thwaites, Jesuit Relations, 60:161. Roubaud sought to deflect blame for the excesses of the August 1757 massacre from his Abenaki charges to un-Christianized Ottawas. This is in contrast to accusations made by Louis Antoine de Bougainville, who blamed the Abenakis for the massacre; Bougainville, Adventure in the Wilderness, 172.

35. Boston Evening Post, March 2, 1759; Brett Rushforth, Bonds of Alliance: Indigenous and Atlantic Slaveries in New France (Chapel Hill: University of North Carolina Press, 2012), 353-64. 
governments and favor in legal disputes and secure their claims to sovereignty. Most were disappointed on all fronts. Tribal petitions from throughout the era asking for redress or demanding equitable treatment prominently mention their repeated military service. It is clear that a few groups benefited directly or indirectly from their military service, but the vast majority lost almost everything in the long run. In the face of intense pressure to surrender their lands and acculturate, few groups held on to their lands permanently or remained politically autonomous through the eighteenth and nineteenth centuries - but not for want of trying. ${ }^{36}$ Groups adopted myriad strategies to maintain their independence and carve out cultural space for themselves; their current descendants are a testimony to that resiliency. At risk of drastically oversimplifying the complex relations between New England Native groups and provincial governments, and at risk of ignoring the great cost that all Indian groups in the area paid in the colonial wars, a political cost-benefit analysis reveals that there were both winners and losers when it came to Indian military service.

One group that was somewhat successful in using its military service to secure political aims, at least in the short run, was the Mashpees. At the time of the French and Indian War, the tribe was involved in a dispute with its provincially appointed guardians after the overseers sold reservation land without the tribe's permission. The Mashpees petitioned the Massachusetts General Court for the removal of the guardians and for the legislature to grant them greater autonomy in managing their own affairs. In their memorials they were quick to remind officials of their loyal service in the army. "We have never been against the English," the Native minister Solomon Briant wrote in one, "but united with them against their enemies." Though certainly other issues were at play, in this instance at least the Mashpee petitions garnered sympathy from the colony. The guardianship system was removed and for a time the tribe gained a modicum of political freedom. ${ }^{37}$

Another group of so-called winners, again in the short run, were descendants of a small band of Wampanoag soldiers who had served throughout

36. Mandell, Tribe, Race, History, 42-69; O’Brien, Dispossession by Degrees, 119-22.

37. Mandell, “'We as a tribe, will rule ourselves': Mashpee's Struggle for Autonomy, 1746-1840," in Colin G. Calloway and Neal Salisbury, eds., Reinterpreting New England Indians and the Colonial Experience (Boston: Colonial Society of Massachusetts, 2003), 301-4; Peter Karsten, Between Law and Custom: "High" and "Low" Legal Cultures in the Lands of the British Diaspora-The United States, Canada, Australia, and New Zealand, 1600-1900 (New York: Cambridge University Press, 2002), 56 . 
the late seventeenth and early eighteenth centuries in colonial armies. As encroachment and debt forced many Wampanoags off their lands in Little Compton, Tiverton, and Dartmouth, then all part of Massachusetts, the group obtained a grant of land for a reservation in Tiverton through the active intercession of an aged Benjamin Church. The land, however, proved unsuitable. So Church, who had been personally supporting many of the soldiers and their families on lands he owned in newly created Freetown, swapped his lands for the Tiverton grant. This led to the creation of the Freetown-Watuppa reserve in 1702, which provided the Wampanoag veterans, their families, and their descendants with a stable, secure, and (for a time) inalienable land base that ensured the community's survival. Though they eventually faced the same cultural and economic pressures that plagued other Native communities in the region, the reservation's residents nevertheless remained a vital community for almost two centuries, until broken up by state officials at the end of the nineteenth century. Later generations of Wampanoags from the Freetown reservation proved equally dependable as soldiers. Men from this reserve were the Indians serving (and dying) in the Sixth Massachusetts Regiment at Louisburg in 1745, mentioned earlier. ${ }^{38}$

Another group that benefited from its service in the colonial wars was a little-known population of mixed-race Anglo-Nauset families from outer Cape Cod who were among the so-called New England Planters, New England migrants who settled in Nova Scotia starting in the 1760s. In the aftermath of the French and Indian War, these families took advantage of grants offered by the British to resettle lands left vacant by the expulsion of the Acadians to pursue fishing, farming, and whaling. ${ }^{39}$ Amid the several

38. Mandell, Tribe, Race, History, 7, 135, 137, 153, 156-60, 212, 223; Petition of Benjamin Church, June 19, 1710, Mass. Archives, 30:72-74; Petition of James Noby and George, Tiverton [Mass.], March 20, 1700, Mass. Archives, 30:453; Benjamin Church to William Stoughton, Tiverton [Mass.], May 30, 1700, Mass. Archives, 30:455; Massachusetts House of Representatives, June 28, 1700, Mass. Archives, 30:458; "Resolution re: Tiverton Indians," February, 21, 1701, Mass. Archives 30: 478; Massachusetts House of Representatives, April 4, 1709, Mass. Archives, 243:14; "A Schedule of Both the Indians Land and to Whom They Severally Belong Lying in Freetown,” February 3, 1764, Mass. Archives, 33:269-73; Hugo A. Dubuque, Fall River Indian Reservation (Fall River, Mass.: n.p., 1907). Although not currently a federally recognized tribe, descendants of the Wampanoag soldiers still reside in that area and are recognized by Massachusetts as the Assonet or Fall River Band of Wampanoags.

39. David Jaffee, People of the Wachusett: Greater New England in History and Memory, 1630-1860 (Ithaca: Cornell University Press, 1999), 170, notes that the south shore of Nova Scotia was settled by families from "Cape Cod fishing communities" and that "many had personal experience" of the region from their participa- 
thousand English colonists who arrived after the war were at least a hundred mixed-race individuals. They settled areas they or their Wampanoag and Nauset relations had just recently cleared of Acadians. Members of the Wixoms, for instance, had intermarried with the Nauset as early as the seventeenth century and yet were well-integrated into Anglo communities on the Cape, particularly Yarmouth. The decision of later members, such as Robert and Elijah Wixom, to join Gorham's Rangers during King George's War is telling. Although the cousins appear as Anglos in local vital records, at the time they joined it the renowned company comprised Indians exclusively. The unit played a pivotal role in British ethnic-cleansing operations that removed the Acadians, paving the way for the English (and their) settlement. ${ }^{40}$ Although they never used the term to describe themselves, métis members of the Wixom family, like others from the area, maintained close ties with their Native relations, going to war with them and migrating with them to Nova Scotia. ${ }^{41}$

tion in "military expeditions." See also W. P. Bell, The "Foreign Protestants" and the Settlement of Nova Scotia: The History of a Piece of Arrested British Colonial Policy in the Eighteenth Century (1961; repr., Fredericton, N.B.: Acadiensis Press, 1990); Margaret Conrad, ed., They Planted Well: New England Planters in Maritime Canada (Fredericton, N.B.: Acadiensis Press, 1988); Margaret Conrad and Barry Moody, eds., Planter Links: Community and Culture in Colonial Nova Scotia (Fredericton, N.B.: Acadiensis Press, 2001).

40. Robert Wixom (II), was born in 1729 in Yarmouth; Robert M. Sherman and Ruth Wilder Sherman, comps., Vital Records of Yarmouth, Massachusetts to the Year 1850, vol. 1 (Providence: Society of Mayflower Descendants in the State of Rhode Island, 1975), 105, 108. Elijah Wixom (1735-1806) was only fourteen when he joined the rangers; Justin H. Wixom, Wixom Family History (Salt Lake City: n.p., 1963), 10; Joseph Gorham, "Return of Troops, Rangers from Nova Scotia," February 23, 1748, Gilder Lehrman Collection, Gilder Lehrman Institute for American History, New York.

41. Massachusetts officials who authored reports on Indian affairs in the commonwealth concluded that the Nausets, though still identifiable, were heavily intermixed with local whites. John Milton Earle, compiling a report in 1859, described the Nausets as having "scarcely any characteristic by which to distinguish its members from the mass of the community with which it is intermingled." Yet he still found an identifiable population of twenty-three families, consisting of 105 "Natives" and 21 related "foreigners." Earle interviewed members who told him most of the tribe descended from mixed-race families formed around 1740, particularly the children of "an Indian mother and white father." Earle also found the tribe heavily intermixed with neighboring Wampanoags. Further, he observed that "nearly all" of the band's members "intermarried with whites, down to the present day," and these mixed-race individuals were "substantially merged in the general community, except a few families who kept to their own kind.” Though such fluid 
Some individual Indians tried this strategy of invoking their past military service for favorable treatment in courts to varying degrees of success. Facing a murder charge and an all-Anglo jury in Connecticut in 1772, Moses Paul reminded the court that his people were "Friends and Allies, and Loyal Subjects to the Crown of England," and he invoked the patriotism of his Wampanoag father, a member of Gorham's Rangers and, as he claimed in a deposition, "the first Man that was killed at the Siege of Louisburg." Paul highlighted his own military service as evidence too, reminding the jury that he "faithfully serv[ed] in the late Wars under the Command of Coln Putnam"- he was probably one of the dispatch runners during the siege of Fort William Henry mentioned earlier. ${ }^{42}$ Individuals, sachems, and tribal councils felt their loyalty in wartime guaranteed certain rights and protections. But in the end, aside from a few instances, their military service did little to change their subordinate status with provincial governments.

That Natives expected their steadfast loyalty and the service of their men in colonial armies to earn them the right to fair treatment and a say in running their own affairs is perhaps clearest in the actions of the Mohegans. Ever more frustrated at the colony level with attempts for redress over fraudulent land sales earlier in the century, the tribe had in the past received a more sympathetic ear from royal officials. So, though the Mohegans signed up in large numbers for the Connecticut provincial service in the 1740s and again at the start of the French and Indian War, they eventually withdrew that military support. Using the enlistment of their young menthe warriors-to secure political ends, the tribe abandoned the Connecticut

racial dynamics seem rare in New England, the Anglo-Nauset families of eastern Cape Cod in the eighteenth and nineteenth centuries constituted what could be easily characterized as a métis community. John Milton Earle, Report to the Governor and Council, Concerning the Indians of the Commonwealth, under the Act of April 6, 1859 (Boston: W. White, 1861), 108-11; “The Massachusetts Indians,” in Fourth Annual Report of the Board of State Charities of Massachusetts (Boston: Wright and Potter, 1868), 21-22.

42. Petition of James Noby and George, Tiverton [Mass.], March 20, 1700, Mass. Archives, 30:453; Petition of Simon Popmonnet et al., Mashpee, May 24, 1700, Mass. Archives, 30:456; Petition of Natick Indians, May 21, 1700, Mass. Archives, 30:457; Mohegan Indians to George II, May 1736, folder 788, Facsimile Documents, Huntington Library, San Marino, Calif.; David W. Conroy, "The Defense of Indian Land Rights: William Bollan and the Mohegan Case in 1743," Proceedings of the American Antiquarian Society 103, no. 2 (1993): 395-424; Ava Chamberlain, "The Execution of Moses Paul: A Story of Crime and Contact in Eighteenth-Century Connecticut," New England Quarterly 77, no. 3 (2004): 438-39. 
service. After 1757 Mohegan men instead enlisted in British army ranger companies. They entered the Crown's service to gain a powerful political ally, Sir William Johnson, the British superintendent of Indian affairs. The tribe hoped Johnson, one of the highest-ranking royal officials in America and an influential figure during the war, would aid their cause. As late as the 1760s the Mohegans still hoped he could influence the outcome of their lawsuit with Connecticut. ${ }^{43}$

In the end however, the Mohegans were perhaps the biggest losers. They proved the most loyal military ally of all the region's tribes, and they cultivated a reputation as the most dependable and capable Indian soldiers from southern New England. Despite loyal service in every colonial war in the region from 1636 to 1763 , the tribe lost most of its lands in the dispute with the province. ${ }^{44}$ Throughout the protracted legal case the Mohegans argued they were independent allies rather than subjects of Connecticut. They understood themselves a free nation and entitled to "continued existence as a people," according to the historian Craig Yirush. The Mohegans saw the colony's seizure of their lands in the early eighteenth century as a violation of that sovereignty. While their position was upheld by earlier royal commissions arbitrating the dispute, the Mohegans lost their 1743 and 1773 appeals. Generations of Mohegan men fought and died for the colony while the case was deliberated. When the ruling came down in favor of Connecticut interests in 1773, the Mohegans felt deeply betrayed. Years of loyal service, hundreds of Mohegan lives sacrificed to protect the colonies and expand the empire, and this was their reward. It is no surprise that Mohegan veterans and their families, along with numerous other former Indian soldiers from various Connecticut, Rhode Island, and Long Island tribes, were prominent in the panregional Indian revitalization movement following the war, known as the Brothertown migration. The movement's titular leader, the Reverend Samson Occum, had never been a soldier in the

43. In addition to leveraging their service to the Crown for political support, letters from Mohegan leaders to the Mohawks and Mohicans show they were just as interested in maintaining favor and connection with other tribes; The Papers of Sir William Johnson, 14 vols. (Albany: University of the State of New York, 1921-65), 2:836-37; 5:27, 459-60; Conroy, "The Defense of Indian Land Rights."

44. Den Ouden, Beyond Conquest, 91-94; Mark D. Walters, "Mohegan Indians v. Connecticut (1705-1773) and the Legal Status of Aboriginal Customary Laws and Government in British North America," Osgoode Hall Law Review 33, no. 4 (1995): 785-829; "To Do Good to My Indian Brethren": The Writings of Joseph Johnson, 1751-1776, ed. Laura J. Murray (Amherst: University of Massachusetts Press, 1998), 33-40. 
colonial wars, but just about every other man in the movement had been. His brothers and sons served in the army, as did most of the early Brothertown leaders. And though the Mohegan Joseph Johnson Jr., another of the movement's leaders, was too young to have served, his father, Joseph Johnson Sr., had died in the fighting. He was a commissioned officer in the renowned Rogers' Rangers and arguably the most famous Connecticut Indian soldier of the French and Indian War. On top of the fact that many of the men in the movement were veterans, they were also part of a faction within the regions' tribes that embraced the English language, literacy, protestant Christianity, concepts of European land tenure, English-style agriculture and husbandry, and even aspects of Anglo-American race prejudice. Though a minority among the region's Native population, a significant number decided to leave New England. They chose to start over in Oneida country under Iroquois rule. So a significant portion of Mohegan veterans clearly felt that they would never be treated fairly in New England, which they had fought so hard to protect. ${ }^{45}$

Serving in the military in the colonial wars offered Indian men from southern New England a setting in which to prove themselves in ways important to Native concepts of masculinity, and the wages soldiers earned provided short-term economic benefits for Indian families. But few long-term political benefits accrued from continued service, especially in terms of recognition of a tribe's cultural and political autonomy. Yet, despite having been conquered or incorporated into the colonies generations earlier (with the exception of the Mohegans), being restricted to reservations "behind the frontier" and relegated to second-class social status, settlement Indians from southern New England during the eighteenth century clearly did not watch the major events of the era from the sidelines. Active participants, they took part for their own cultural and economic reasons and in many cases to further tribal political agendas. But the costs of repeated military deployments by Native men—death, disease, injury, and captivity—far outweighed any short-term economic, cultural, or political benefits.

45. Craig Bryon Yirush, "Claiming the New World: Empire, Law, and Indigenous Rights in the Mohegan Case, 1704-1743," Law and History Review 29, no. 2 (2011), 368; Conroy, "The Defense of Indian Rights"; Paul Joseph Grant-Costa, "The Last Indian War in New England: The Mohegan Indians v. the Governour and Company of the Colony of Connecticut, 1703-1774" (Ph.D. diss., Yale University, 2008); Johnson, "To Do Good to My Indian Brethren," 9-29. 
Military service severely affected the composition of their communities, which, in turn, undermined the legal status of indigenous people in the eyes of white authorities and further fueled the already prevalent myth of Indian extinction. The most significant consequence was the decline in the number of adult Indian men in New England Indian communities, as seen at Herring Pond, Potanomecut, Niantic, Mashantucket, and Lyme. Few men remained in Native enclaves after the French and Indian War. Impoverished widows and orphans of Indian soldiers who never returned were common in subsequent decades. Indian women had long outnumbered Indian men, but wartime losses greatly accentuated this pattern. Indeed, the shortage of Indian men after the war became acute. More Indian deaths during the Revolutionary War only exacerbated the trend. Given the demographic imbalance this created, far too few adult males and too many adult females, Indian women looked outside their communities for partners and spouses. Following the colonial wars, though intermarriage and intermixture between whites and Indians did happen, relationships between African males and Indian women were far more common. Mixed-race offspring of these Indian-African couplings, characterized as "mustee" or "mulatto" by whites, fueled the perception that Indians were dying out. Indeed, early nineteenth-century chroniclers often noted, either romantically or derisively, the death of the "last" Indian in their towns. Unintentionally ironic, many also noted the spouses, siblings, children, or grandchildren of these individuals. They dismissed them, however, because they were mixed-race and therefore not "real" Indians in their eyes-this is in spite of the fact that Indians determined membership within their tribes in different ways and often proved remarkably flexible and adaptive in incorporating newcomers. Native communities persisted, but white New Englanders were increasingly blind to their existence. ${ }^{46}$ To whites, mixed-bloods could be

46. Petition of Isaac James et al., November 19, 1757, Mass. Archives, 33:10; Jack Campisi, The Mashpee Indians: Tribe on Trial (Syracuse: Syracuse University Press, 1991), 87-89; Francis G. Hutchins, Mashpee: The Story of Cape Cod's Indian Town (West Franklin, N.H.: Amarta Press, 1979), 79-88; Den Ouden, Beyond Conquest, 30-38; Mandell, Tribe, Race, History, 39-40, 42-59; Daniel Mandell, "Shifting Boundaries of Race and Ethnicity: Indian-Black Intermarriage in Southern New England, 1760-1880," Journal of American History 85, no. 2 (1998): 466501; Ruth Wallis Herndon and Ella Wilcox Sekatau, "The Right to a Name: Narragansett People and Rhode Island Officials in the Revolutionary Era," in Peter C. Mancall and James H. Merrell, eds., American Encounters: Natives and Newcomers from European Contact to Indian Removal, 1500-1850 (New York: Routledge, 2000), 437-39; Jack D. Forbes, Africans and Native Americans: The Language of Race and the Evolution of Red-Black Peoples (Urbana: University of Illinois Press, 1993), 
removed from reservation rolls and reserves broken up because, to them, the inhabitants were not Indians. And then the land, of course, could be sold to Anglo-Americans. Whites therefore emphasized the effects of Indian military service in the colonial wars while failing to recognize the significant value of that service in securing their lands and security or its terrible cost for Indian communities.

215-17; Donna Keith Baron, J. Edward Hood, and Holly Izard, "They Were Here All Along: The Native American Presence in Lower-Central New England in the Eighteenth and Nineteenth Centuries," William and Mary Quarterly 53, no. 3 (1996): 561-86. 